\title{
Pengaruh Perangkat lunak Managemen Referensi Pada Peningkatkan Motivasi Publikasi Para Pendidik
}

\author{
${ }^{1}$ Sani Muhamad Isa, ${ }^{2}$ Benfano Soewito, ${ }^{3}$ Fergyanto E. Gunawan \\ ${ }^{1,2,3}$ Master Teknik Informatika, Universitas Bina Nusantara, Jl. Kebon Jeruk No. 27 Jakarta 11530 \\ e-mail: ${ }^{1}$ sani.m.isa@binus.ac.id, ${ }^{2}$ bsoewito@binus.edu, ${ }^{3}$ fgunawan@binus.edu
}

\begin{abstract}
Abstrak. Jumlah publikasi dari Indonesia sangat sedikit dibanding dengan negara tetangga seperti Malaysia dan Singapura. Padahal jumlah tenaga pendidik Indonesia sangat banyak dibanding dengan Negara tetangga. Hal ini disebabkan oleh beberapa faktor yang membuat minat menulis dari pendidik sangat rendah, diantaranya adalah ketidaktahuan dalam penggunaan perangkat lunak. Oleh karena itu kami tertarik untuk melakukan penelitian untuk mengkaji pengaruh penguasaaan perangkat lunak terhadap minat menulis dari tenaga pendidik. Dalam penelitian ini kami meneliti para pendidik Sekolah Dasar di daerah Cipayung Jakarta Timur. Penelitian ini menggunakan metode kuesioner kepada tenaga pendidik di daerah Cipayung Jakarta Timur. Hasil penelitian menunjukkan bahwa pengenalan dan pelatihan perangkat lunak kepada para tenaga pendidik dapat meningkatkan minat untuk penulisan karya ilmiah. Disamping itu perlu diadakan penyuluhan secara rutin dan berkesinambungan dalam hal publikasi bagi guru-guru SD sampai SMA untuk meningkatkan minat penulisan karya ilmiah.
\end{abstract}

Kata kunci: perangkat lunak, publikasi, minat menulis, dan tenaga pendidik

\section{Pendahuluan}

Kemampuan untuk menulis artikel ilmiah di Indonesia sangat rendah dibanding dengan negara-negara tetangga. Hal ini disebabkan oleh beberapa faktor, yaitu ketidaktahuan bagaimana cara menulis karya ilmiah yang baik, kemampuan membaca dan menulis dalam bahasa Inggris yang masih rendah (Lin, Cheng, \& Lin, 2014) dan juga kesulitan dalam menulis dengan menggunakan perangkat lunak. Salah satu contoh kesulitan pada saat menulis karya ilmiah adalah pada saat membuat kutipan dan daftar pustaka. Kemampuan menggunakan perangkat lunak dalam menulis karya ilmiah sebenarnya berhubungan dengan pengetahuan si penulis sendiri. Dari hasil penelitian pada kegiatan pengabdian pada masyarakat untuk tenaga pendidik di daerah Cipayung, Jakarta Timur, diperoleh fakta bahwa tidak ada satupun tenaga pendidik yang mengenal perangkat lunak yang membantu dalam membuat kutipan dan daftar pustaka atau dalam bahasa inggris disebut reference manager software.

Definisi karya ilmiah menurut (Tanjung, 2005) adalah hasil pemikiran seorang ilmuwan (berupa hasil pengembangan) yang ingin mengembangkan ilmu pengetahuan, teknologi, dan seni yang diperoleh melalui kepustakaan, kumpulan pengalaman, penelitian dan pengatahuan orang sebelumnya. Pengertian karya ilmiah ini sedikit berbeda dengan (Pateda \& Pulubuhu, 1993) yang menjelaskan bahwa karya ilmiah adalah hasil pemikiran ilmiah pada suatu disiplin ilmu tertentu yang disusun secara sistematis, ilmiah, logis, benar dan bertanggung jawab, serta menggunakan bahasa yang baik dan benar. Jadi, karya ilmiah ditulis bukan sekedar untuk mempertangungjawabkan penggunaan sumber daya penelitian (uang, bahan, dan alat), tetapi juga untuk mempertanggungjawabkan penulisan karya ilmiah tersebut secara teknis dan materi. Hal 
ini terjadi karena suatu karya ilmiah dibaca dan dipelajari oleh orang lain dalam kurun waktu yang tidak terbatas sebagai sarana mengembangkan ilmu pengetahuan, teknologi dan seni (Arum, 2015).

Format sebuah karya ilmiah sangat perlu disesuaikan dengan simtematika yang diminta oleh media publikasi, baik itu jurnal ataupun prosiding, sebab bila tidak sesuai dengan format yang disediakan maka besar kemungkinan karya ilmiah yang kita tulis tidak akan dimuat atau ditolak, (Firman, 2014). Padahal karya ilmiah akan mengandung sebuah nilai apabila sudah dipublikasikan. Format yang diminta untuk penulisan karya ilmiah pada umumnya terdiri dari beberapa bagian yaitu: abstrak, pendahuluan, tinjauan pustaka, metodologi, hasil dan pembahasan, kesimpulan dan daftar pustaka.

Dalam penelitian ini kami tertarik untuk mengkaji pengaruh penggunaan perangkat lunak untuk mengelola pustaka dan kutipan terhadap minat menulis di kalangan guru-guru SD sampai SMA di daerah Cipayung, Jakarta Timur. Berdasarkan pendahuluan di atas, maka kami mengumpulkan data berdasarkan kuesioner. (1) Pertama kami ingin mendapatkan data berapa banyak diantara guru-guru tersebut yang sudah pernah mempublikasikan karya ilmiah-nya. (2) Kedua, kami ingin mengetahui hambatan-hambatan yang dialami oleh guru-guru sehingga tidak berminat untuk membuat publikasi karya ilmiah.

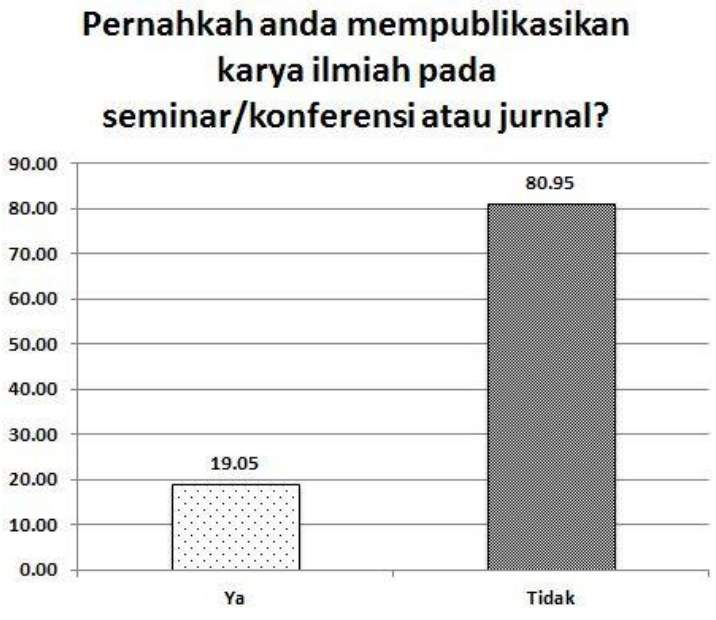

(a)
Apa hambatan utama anda saat akan/memulai menuliskan karya ilmiah?

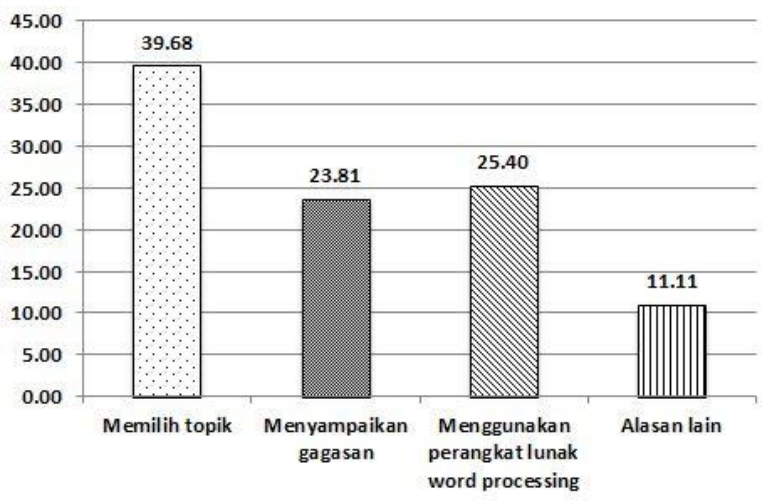

(b)

Gambar 1. Grafik jumlah guru yang pernah membuat publikasi (a) dan hambatannya (b)

Hasil dari kuesioner tersebut dapat dilihat pada gambar 1. Dari gambar 1 terlihat bahwa hanya $19.05 \%$ guru yang pernah menulis karya ilmiah dan mempublikasikannya. Sisanya sebanyak $80.95 \%$ belum pernah menulis atau publikasi di seminar ataupun jurnal. Menurut kami disini ada sebuah masalah mengapa guru-guru tidak ada minat untuk menulis dan mempublikasikannya. Untuk itu kami mengambil data untuk mengetahui hambatan hambatan yang ditemui oleh guru-guru sehingga tidak ada minat untuk menulis. Pertanyaan yang kami ajukan adalah: apa hambatan utama anda saat akan memulai menuliskan karya ilmiah? Jawabannya kami sediakan menjadi empat, yaitu: hambatan dalam memilih topik, hambatan dalam menyampaikan gagasan, hambatan karena tidak mahir dalam menggunakan perangkat lunak dan hambatan karena alasan yang lainnya. Dari hasil kuesioner menunjukkan bahwa hambatan dalam 
memilih topik adalah merupakan hambatan terbesar yaitu sebesar 39.68\%. Untuk masalah ini akan kami bahas dalam tulisan yang akan datang. Dalam penelitian ini kami akan fokus kepada masalah hambatan karena penggunaan perangkat lunak. Dalam penggunaan perangkat lunak ini kami perkenalkan kepada guru-guru dua buah perangkat lunak yang dapat membantu penulisan karya ilmiah, yaitu Microsoft word dan Mendeley. Guru-guru sudah mengenal Microsoft word dan sudah dapat menggunakannya dengan baik tetapi masalah muncul ketika melakukan kutipan dan penulisan daftar pustaka, seperti yang terlihat pada gambar 2 .

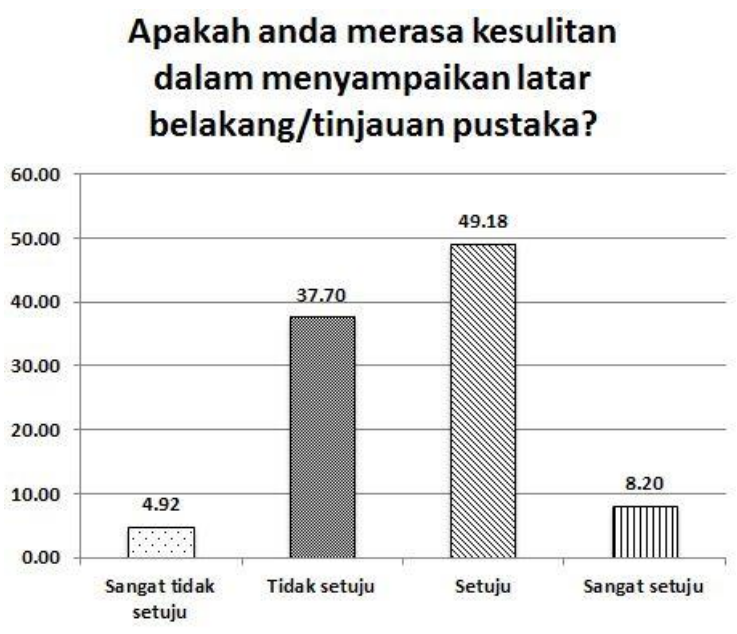

(a)
Apakah anda merasa kesulitan dalam melakukan sitasi atau menuliskan daftar pustaka?

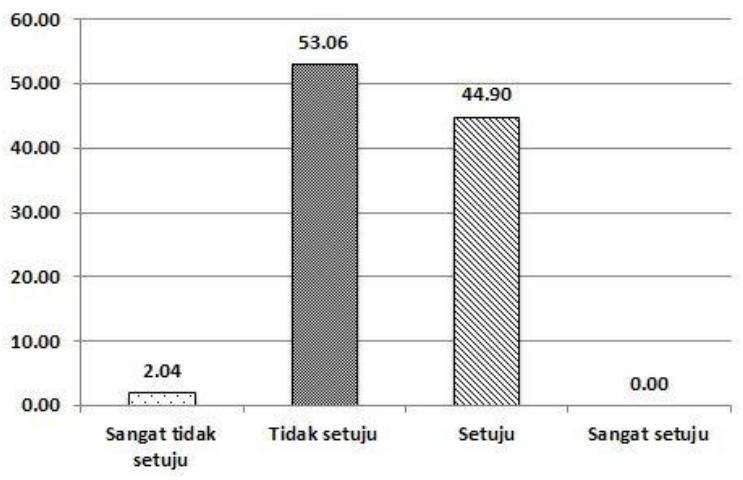

(b)

\section{Gambar 2. Grafik jumlah kesulitan menulis tinjauan pustaka (a) dan jumlah kesulitan dalam menuliskan kutipan dan daftar pustaka (b)}

Dari hasil kuesioner yang ditunjukkan dalam gambar 2, terlihat bahwa guru-guru yang kesulitan dalam menuliskan tinjauan pustaka pada karya ilmiah sebesar $49.18 \%$ setuju dan $8.20 \%$ sangat setuju atau dengan kata lain $57.38 \%$ guru-guru mengalami kesulitan dalam menulis tinjauan pustaka. Sebagian besar guru-guru juga atau $44.90 \%$ mengalami kesulitan dalam melakukan kutipan dan menyusun daftar pustaka. Oleh karena itu dalam pengabdian pada masyarakat kali ini, kami memberikan penyuluhan mengenai perangkat lunak reference manager untuk membantu para guru dalam menuliskan kutipan dan menyusun daftar pustaka.

\subsection{Perangkat lunak untuk mengatur kutipn dan daftar pustaka}

Manajemen daftar pustaka adalah salah satu aspek yang rumit bagi seorang peneliti atau penulis sebuah karya tulis (Gilmour \& Cobus-Kuo, 2011). Perangkat lunak untuk mengatur daftar pustaka ini banyak tersedia di internet seperti: Bebop, Citavi, Endnote, Mendeley dan sebagainya. Dalam pengabdian pada masyarakat untuk para guru di Cipayung ini kami mengenalkan perangkat lunak mendeley.

Mendeley merupakan salah satu perangkat lunak manajemen referensi berbasis open source yang dapat diperoleh secara gratis dan mendukung berbagai platform seperti Microsoft Windows, Apple MacOS, maupun Linux. Versi terbaru dari Mendeley bahkan sudah mendukung sistem operasi Android, sehingga perangkat ini dapat digunakan pada ponsel. Mendeley merupakan kombinasi dari aplikasi desktop dan 
situs web yang dapat digunakan untuk mengelola, berbagi, dan mencari referensi maupun kontak. Berikut fitur utama dari Mendeley Desktop (Mendeley, n.d.):

- Ekstraksi detil dokumen (judul, penulis, nama jurnal, dll.) dari paper ke dalam database daftar pustaka.

- Pengelolaan referensi yang efisien dengan menyediakan "live" full-text search terhadap seluruh paper dalam database.

- Berbagi pakai sebagian atau semua dokumen pada database dengan pengguna lain serta sinkronisasi pustaka referensi dengan data yang tersimpan di server web Mendeley.

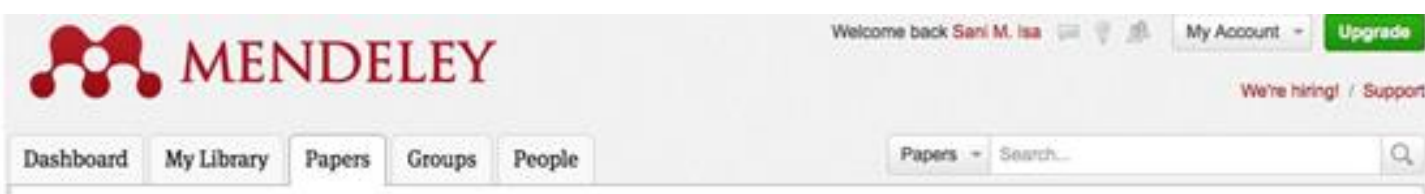

\section{Papers}

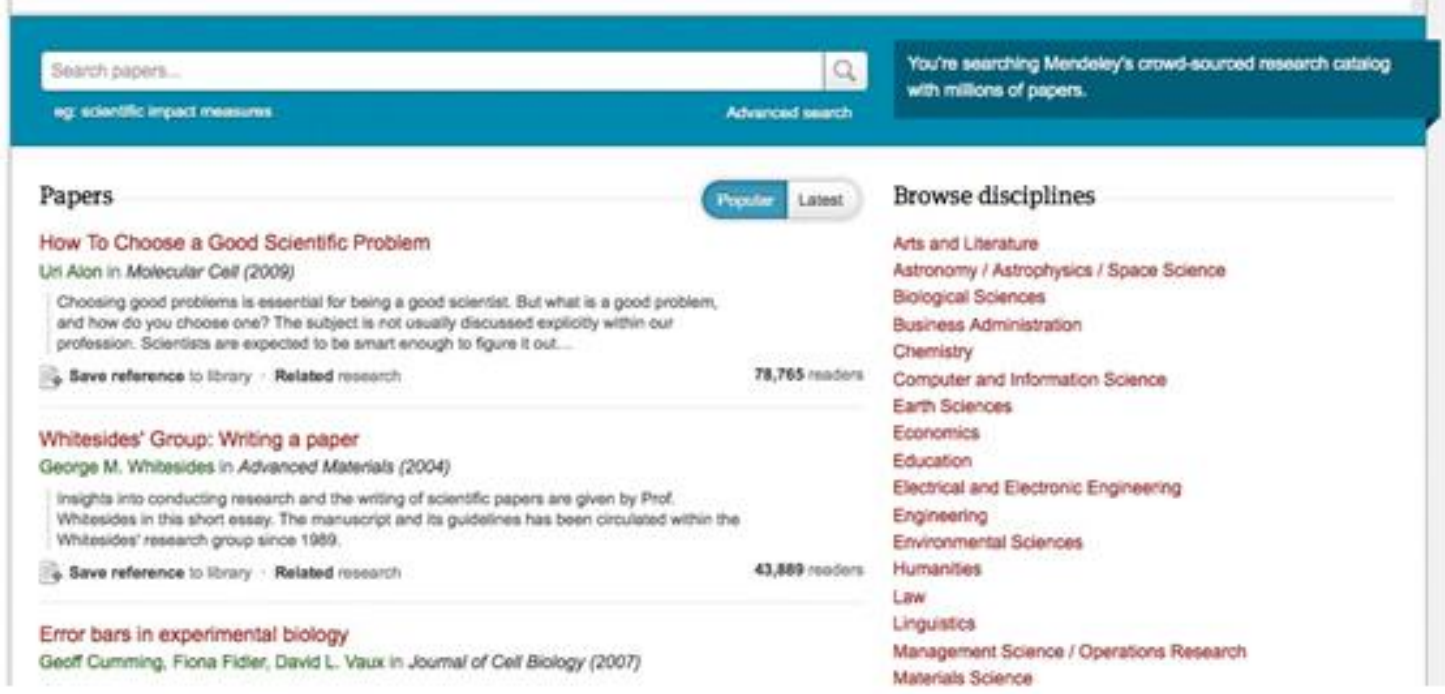

Gambar 3. Tampilan situs web Mendeley setelah pengguna log in ke dalam sistem

Gambar 3 memperlihatkan tampilan dari situs web Mendeley setelah pengguna melakukan login ke dalam sistem dan memilih tab papers yang memperlihatkan daftar paper yang diurutkan berdasarkan tingkat popularitasnya.

\subsection{Evaluasi setelah kegiatan penyuluhan}

Hasil setelah melakukan penyuluhan diukur kembali dengan kuesioner. Pertanyaan yang diajukan adalah: setelah mengikuti kegiatan penyuluhan ini, apakah anda lebih memahami pengelolaan daftar pustaka dengan menggunakan perangkat lunak? Seperti yang terlihat pada gambar 4 (a), hasilnya adalah sebanyak 97.62\% guruguru telah memahami bagaimana dengan bantuan perangkat lunak kita dapat menuliskan daftar pustaka dan kutipan dengan mudah. Feedback terakhir dan yang paling penting yang ingin kita dapatkan adalah: apakah kegiatan semacam ini perlu diadakan lagi pada kesempatan mendatang? Hasilnya menunjukkan bahwa 100\% peserta menginginkan agar kegiatan semacam ini dapat diadakan lagi di lain waktu 
secara berkesinambungan, bahkan keingingan perserta kalau bisa kami dapat menjadi pembimbing dalam membuat karya tulis.

Setelah mengikuti kegiatan workshop ini, apakah anda lebih memahami pengelolaan referensi pada perangkat lunak word processing?

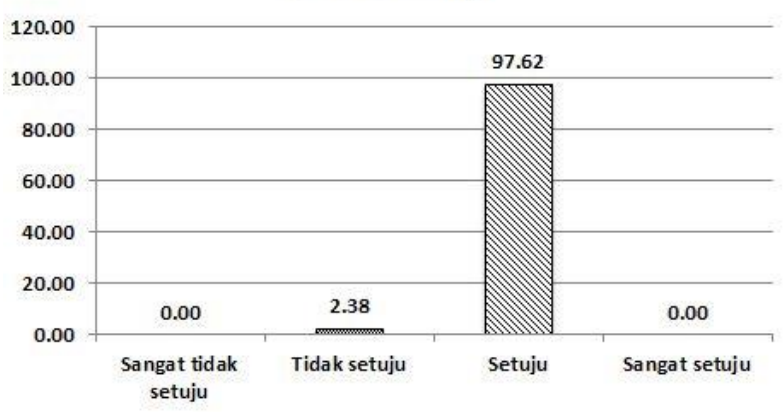

(a)
Apakah kegiatan semacam ini perlu diadakan lagi pada kesempatan mendatang?

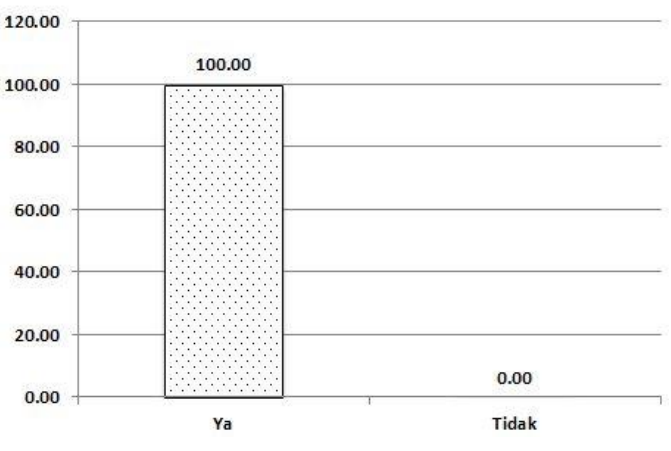

(b)

Gambar 4. Grafik tentang pemahaman penggunaan perangkat lunak untul pengelolaan daftar pustaka (a) dan kegiatan penyuluhan ini perlu dilakukan lagi (b)

\section{Kesimpulan dan Saran}

Berdasarkan hasil kuesioner maka ditemukan beberapa masalah yang menjadi hambatan dalam minat para guru untuk menulis karya ilmiah. Selain hambatan mengenai pemilihan topik dan mengembangkan gagasan, salah satu hambatan yang lain adalah dalam menuliskan kutipan dan menulis daftar pustaka. Ada sebesar $44.9 \%$ dari guru-guru di daerah Cipayung, Jakarta Timur yang mengalami hambatan dalam melakukan kutipan dan membuat daftar pustaka. Oleh karena itu dalam penyuluhan ini kami mengambil tema publikasi dengan bantuan perangkat lunak Microsoft word dan digabung dengan perangkat lunak manajemen referensi. Setelah dilakukan penyuluhan guru-guru menjadi lebih berminat dalam menulis karya ilmiah karena penulisan kutipan dan daftar pustaka bukan menjadi hambatan lagi bagi mereka, sebanyak 97.62\% guruguru dapat memahami bagaimana mudahnya dalam menulis kutipan dan daftar pustaka menggunakan perangkat lunak, yang dalam hal ini kami memberikan penyuluhan dengan perangkat manajemen referensi Mendeley. Perangkat lunak Mendeley dapat di unduh secara gratis di websitenya. Akhirnya semua guru ingin supaya kegiatan semacam ini dilakukan secara terus menerus dan berkesinambungan.

Berdasarkan kesimpulan di atas, peneliti mengusulkan beberapa rekomendasi bagi pengembang pendidikan, penelitian lebih lanjut, dan pihak terkait sebagai berikut: (1) Untuk meningkatkan minat menulis diantara para guru-guru maka perlu dilakukan penyuluhan secara berkesinambungan; (2) Supaya setiap dosen yang sudah berpengalaman membuat karya ilmiah dapat menjadi pembimbing bagi para guru-guru dengan mengadakan pertemuan secara rutin; (3) Sebaiknya kegiatan penyuluhan untuk meningkatkan minat menulis karya ilmiah ini dilakukan di semua pelosok tanah air, sehingga akan meningkatkan jumlah karya tulis secara nasional. Oleh karena itu kami menghimbau teman-teman dosen untuk melakukan kegiatan yang sama di daerahnya masing-masing. 


\section{Ucapan Terimakasih}

Kami ingin mengucapkan terimakasih kepada Ibu Retno Dewanti sebagai penyelenggara kegiatan pengabdian pada masyarakat dengan tema penyuluhan publikasi bagi para guru-guru di Cipayung, Jakarta Timur, dan Bapak Hasan Gozali atas bantuannya untuk menyebar dan mengumpulkan kuesioner dari para peserta.

\section{Daftar pustaka}

Arum, I. M. (2015). Konsep Dasar Menulis Karya Ilmiah. Retrieved September 23, 2015, from http://www.kompasiana.com/kangimang/konsep-dasar-menulis-karyailmiah_5520ee3d8133110f7719f832

Firman, H. (2014). Menulis Karya Ilmiah. Retrieved September 23, 2015, from http://www.academia.edu/9451142/MENULIS_KARYA_ILMIAH

Gilmour, R., \& Cobus-Kuo, L. (2011). Reference management software: A comparative analysis of four products. Issues in Science and Technology Librarianship, 66. http://doi.org/10.5062/F4Z60KZF

Lin, M.-C., Cheng, Y.-S., \& Lin, S.-H. (2014). Development of a research article writing motivation inventory. TESOL Quarterly, 48(2), 389-400.

Mendeley. (n.d.). What is Mendeley? Retrieved September 23, 2015, from http://support.mendeley.com/customer/portal/articles/227875-what-is-mendeley

Pateda, M., \& Pulubuhu, Y. P. (1993). Bahasa Indonesia sebagai mata kuliah dasar umum. Nusa Indah.

Tanjung, B. N. (2005). Pedoman penulisan karya ilmiah. Jakarta: Kencana. 